\title{
Genus Epistrophe Walker, 1852 (Insects: Diptera: Syrphidae) in Northern Iran, with a new species record
}

\author{
Farzaneh Kazerani ${ }^{1}$, Ali Asghar Talebi ${ }^{1 *}$ and Ebrahim Gilasian ${ }^{2}$ \\ 1 Tarbiat Modares University, Department of Entomology, Faculty of Agriculture, P.O.Box: 14115-336, Tehran, I.R. Iran \\ 2 Institute of Plant Protection, Department of Insect Taxonomy, P.O.Box:1454-19395, Tehran, Iran \\ * Corresponding author. E-mail: talebia@modares.ac.ir
}

\begin{abstract}
The genus Epistrophe Walker, 1852 (Diptera: Syrphidae) was studied in the north of Iran. The specimens were collected using malaise traps between March and August 2011. Three species were collected and identified: Epistrophe nitidicollis (Meigen, 1822), E. eligans (Harris, 1780) and E. euchroma (Kowarz, 1885). E. nitidicollis is a new record from Iran. Geographical distribution of the three species are briefly discussed. An identification key with supplementary figures is presented for the species of the genus Epistrophe occurring in this region.
\end{abstract}

The hover flies or flower flies (Diptera: Syrphidae) have a worldwide distribution, with the greatest species diversity in the New World Tropics (Vockeroth 1992). This family comprises about 6000 described species in the world (Thompson 2012), and has been divided into three subfamilies: Microdontinae, Eristalinae and Syrphinae, and fourteen tribes (Thompson and Rotheray 1998).

The species of the genus Epistrophe are medium size hover flies with one generation per year (univoltine) and a long obligate diapause in the larval stage (Schneider 1948, Goeldlin de Tiefenau 1974). Almost 75 species of this genus are described in the world (Speight 2011). Dozkal and Schmidt (1994) listed 23 European species of the genus Epistrophe.

Epistrophe species are associated with forests, where they inhabit in open areas and forest edges, and are found on flowers and sunlit leaves. They probably also occur in the canopy layer. Larvae of E. eligans are aphid predators, and are usually associated with aphids on trees, but also occur on shrubs and tall herbs (Rotheray 1993). Láska and Stary (1980) found larvae of E. nitidicollis on the trees Euonymus sp., Malus sp., Prunus sp. and Sambucus nigra. Mazánek et al. (2001) also report its larvae on Acer pseudoplatanus, Cerasus avium, Carduus sp., Rubus idaeus and Spirea sp. Larvae of E. euchroma have been recorded feeding upon aphids on Euonymus europaeus and Prunus avium. Epistrophe larvae have a typically flattened shape and green color, a good camouflage on tree leaves (Rotheray 1993).

The eggs are laid in aphid colonies in different plants, known mostly on shrubs or trees. Schneider (1948) observed that the eggs hatched after two or three days and the larval stage lasts about eight days, after which it goes into diapause. Diapause occurs between rolled, dead leaves and such in the litter layer (Schneider 1969; Rotheray 1986; Speight 2007). The diapause lasts for up to all types of spring in the following and the duration of the subsequent pupal varies from nine days to one month.

The objective of this study is to provide an initial taxonomic and faunistic insight of the Epistrophe species in the north of Iran.

Material for this study was collected from different habitats in northern Iran using malaise traps (Figure 1). Samples were collected between March and August 2011. The specimens were extracted from the malaise traps and sorted weekly. Then, they were treated with $100 \%$ ethanol for 5 minutes followed by hexamethyldisilazane (HMDS) for $30 \mathrm{~min}$ and finally placed on the glass plate for drying. The dried specimens were then card-mounted and labeled. Morphological terminology follows Van Veen (2004), Stubbs and Falk (1983) and Doczkal and Schmid (1994). All specimens are deposited in the insect collection of the Department of Entomology, Tarbiat Modares University, Tehran.

Three species of the genus Epistrophe were collected and identified from the study area, including two previously reported species: Epistrophe eligans (Harris 1780), Epistrophe euchroma (Kowarz 1885) , as well as one newly recorded species, Epistrophe nitidicollis (Meigen 1822), which is marked with an asterisk in the key. The most abundant species was E. euchroma in the studied area.

\section{KEY TO THE SPECIES OF THE GENUS EPISTROPHE IN NORTHERN IRAN}

1a. Tergite 4 completely black (Figure 2C); Scutellum integrally yellow (Figure 2C)................... Epistrophe eligans 1b. Tergite 4 with yellow band or spots (Figure $2 \mathrm{~A}, \mathrm{~B}$ and $3 A, D)$. Scutellum black with posterior margin yellow (Figure 3A,D). ... 2

2a. Katepisternal patches of hairs clearly separated posteriorly; Tergites 3- 4 with oblique and large spots than tergite 2; Scutellum integrally yellow (Figure 2A, B).

Epistrophe (Epistrophella) euchroma

2b. Katepisternal patches of hairs joined posteriorly; Tergites 3-4 with two yellow bands (Figure 3A, D); Scutellum black with posterior margin yellow (Figure 3A, D). Epistrophe nitidicollis* 


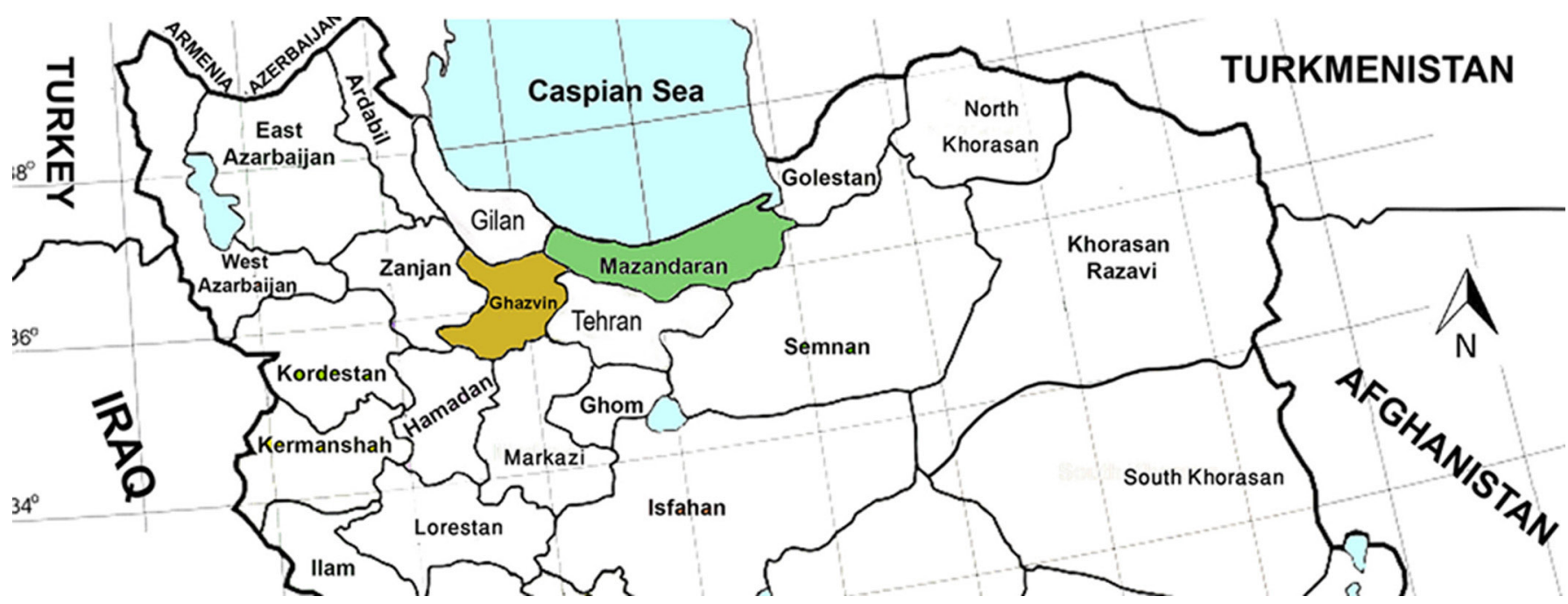

FIGURE 1. Iran's provinces where the Epistrophe species have been collected.

Epistrophe eligans (Harris, 1780) (Figures 2C-D)

Synonyms: Musca elegans Villers, 1789, Syrphus bifasciatus Macquart, 1834, Musca eligans Harris, 1780, Syrphus fulvipes Wiedemann, 1822, Musca interruptus Gmelin, 1790, Syrphus trifasciatus Strobl, 1898, Scaeva volitans Gravenhorst, 1807, Scaeva fenestrata Meigen, 1822.

Material examined: IRAN; Mazandaran Province: Noor, Tangevaz $36^{\circ} 21^{\prime} 55.2^{\prime \prime} \mathrm{N}, 52^{\circ} 06^{\prime} 10.74^{\prime \prime}$ E, 692m, (19), 26.v.2011; leg. M. Kheirandish (Figure 1).

General distribution: Southern Sweden; Iberia; Ireland; Turkey; European parts of Russia; Caucasus (Speight 2011); Lithuania (Lutovinovas et al. 2003); England and Wales (Ball and Morris 2000); Iran (Gilasian 2007).

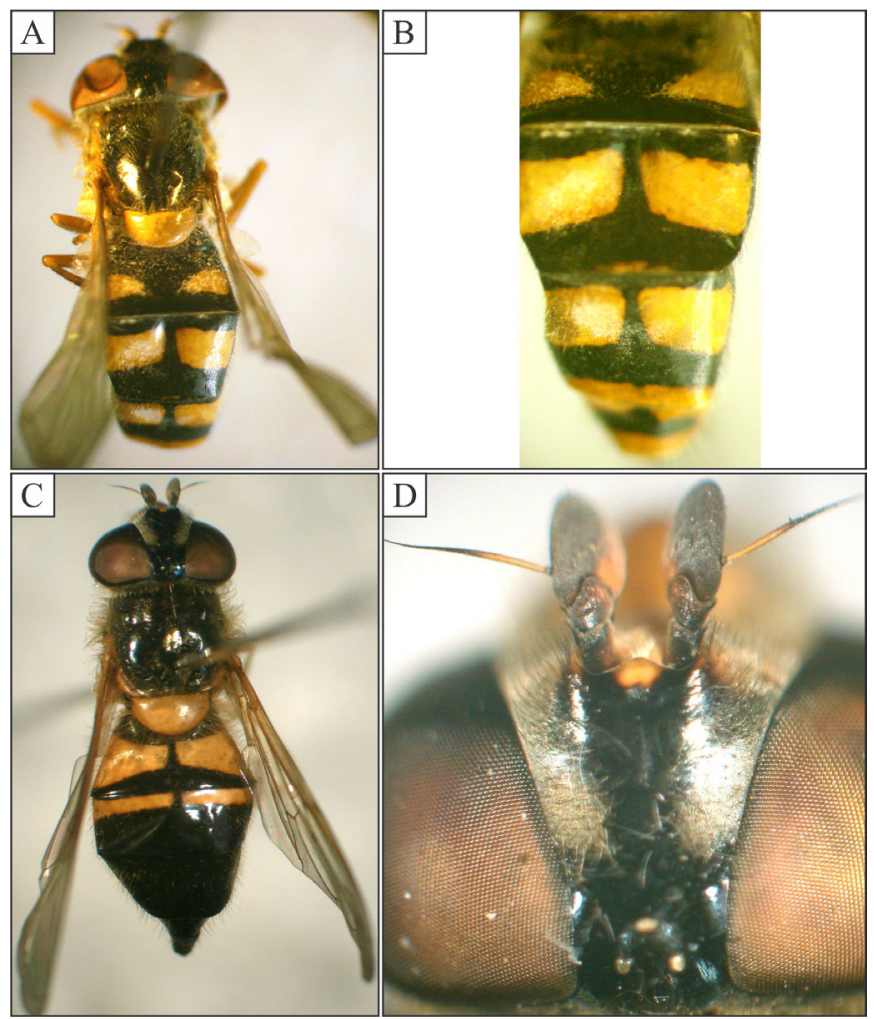

FigurE 2. A-B) Epistrophe euchroma, A) female; B) dorsal view of abdomen; C-D) Epistrophe eligans, C) female; D) Antenna.
Biology: Epistrophe eligans prefer deciduous forest and scrub as well as suburban ornamental gardens (Speight 2011) and also Ball and Morris (2000) stated that adults visit the flowers of trees and bushes, particularly Prunus spinosa and Crataegus and found in Woodland edges, scrub, orchards, mature hedgerows and garden. They appear from end April to end August (Speight 2011), peak in May (Ball and Morris 2000).

Epistrophe (Epistrophella) euchroma (Kowarz, 1885) (Figures 2A-B)

Synonyms: Syrphus euchromus Kowarz, 1885

Material examined: IRAN; Ghazvin Province: Zereshk road $36^{\circ} 25^{\prime} 39.36^{\prime \prime} \mathrm{N}, 50^{\circ} 06^{\prime} 36.9^{\prime \prime} \mathrm{E}, 1997 \mathrm{~m},\left(1 \delta^{\Uparrow} \& 3\right.$ ㅇ) 30.iv.2011; Mazandaran Province: Noor, Gaznasara $36^{\circ} 16^{\prime} 58.08^{\prime \prime} \mathrm{N}, 52^{\circ} 10^{\prime} 55.62^{\prime \prime}$ E, 2013m, (2ㅇ), 26.v.2011; leg. A. Nadimi (Figure 1).

General distribution: Fennoscandia, Pyrenees, Spain (Ball and Morris 2000); Great Britain (southern England), central Europe (Ball and Morris 2000); Russia (Kowalesky 1885); south and eastern Siberia (Yakut) (Violovitsh 1986); Asia (Peck 1988); Serbia (Vujic and Glumac 1994); Iran (Khiaban et al. 1998).

Biology: Epistrophe euchroma usually found in broad leaved forests, rides and wood edges (Falk 1991). There seems to be a preference for old woods (Speight 2011). This species appear from April to June (Falk 1991). In this study, the specimens have been collected in April and May in the woodland area.

\section{Epistrophe nitidicollis (Meigen, 1822) (Figure 3)}

Synonyms: Syrphus nitidicollis Meigen, 1822, Syrphus protritus Osten Sacken, 1877, Stenosyrphus hunteri Curran, 1925.

Material examined: IRAN; Mazandaran Province: Noor, Tangevaz $36^{\circ} 21^{\prime} 55.02^{\prime \prime} \mathrm{N}, 5^{\circ} 06^{\prime} 10.74^{\prime \prime}$ E, 692m, (1여 1 ${ }^{\Uparrow}$ ), 3.viii.2011; leg. M. Kheirandish (Figure 1).

General distribution: Fennoscandia, Iberia, Ireland eastwards through northern, Italy, the former Yugoslavia, Bulgaria, Russia, Siberia, N America from Alaska south to California (Speight 2011), Nederland (Reemer 1999), Korea (Ku 1968). New record to Iranian insect fauna.

Biology: Epistrophe nitidicollis prefer deciduous 

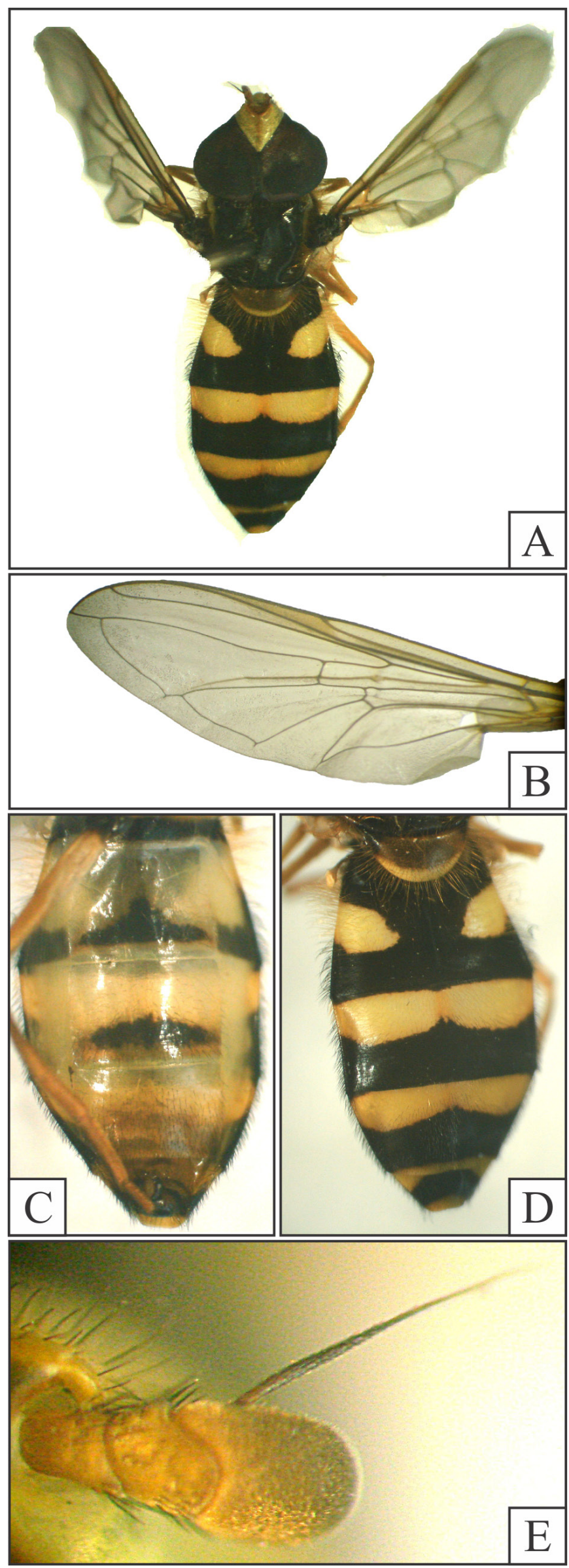

FiguRE 3. Epistrophe nitidicollis, male; A) Adult; B) Wing; C) Ventral view of abdomen; D) Dorsal view of Abdomen; E) Antenna. woodland, scrub and marquis. Adult habitat is largely arboreal and visit flowers. Flying period is from May to July (Speight 2011, Falk 1991). The specimens in this study collected in early August in height altitudes.

Diagnosis: Head: Frons yellow with black hairs; antennae orange, basoflagellomere slightly darkened dorsally dark, arista black (Figure 3E); gena yellow, Mouth edge yellow; Thorax: scutum shiny black, notopleuron yellow, scutellum black, posterior margin yellow with almost black hairs and some yellow hairs; wing basal cell bm and/or br entirely covered by microtrichia (Figure 3B); legs entirely yellow; Abdomen: oval, tergite 1 black, tergite 2 with two yellow large spots, tergites 3-4 with two yellow bands, tergite 5 with narrower yellow band (Figure 3D); sternites white to yellow, sternites 2-3 with black bands (Figure 3C).

The adults of Epistrophe are similar to Syrphus, but their larvae are completely different morphologicaly. Fluke (1950) placed Epistrophe as subgenus of Syrphus. Wirth et al. (1965) recognized Epistrophe as a separate genus from Stenosyrphus (a junior synonym of Melangyna Verral, 1901). Dusek and Laska (1967) followed Wirth et al. (1965) and created a new genus (Epistrophella) for Syrphus euchromus Kowarz, 1885. Vockeroth (1969) indicated the unusual variation in thoracic and abdominal markings of Epistrophe and suggested to use two subgenera: Epistrophe and Epistrophella. The cladistic analysis by Rotheray and Gilbert (1989) placed Epistrophe with Epistrophella, and Meligramma together with Parasyrphus or with Xanthogramma and Doros. The analysis of larval morphology guided Rotheray and Gilbert to synonymize Epistrophella under Meligramma. Mengual et al. (2008) using molecular characters resolved Epistrophella close to Xanthogramma, in agreement with more recent larval evidence (Rotheray and Gilbert 1999). The clade Epistrophella + Xanthogramma was placed as sister group of Chrysotoxum + Epistrophe. The molecular evidence disagrees with the results by Rotheray and Gilbert as Espitrophella and Meligramma were resolved in different clades.

ACKNOWLEDGMENTS: We would like to thank the Department of Entomology, Tarbiat Modares University for providing financial support for this research. Our cordial thanks are expressed to Dr. Wouter Van Steenis for revision and very helpful comments on this paper and Mr. A. Nadimi and M. Kheyrandish for collection of specimens studied in this research.

\section{Literature Cited}

Ball, S.G. and R.K.A. Morris. 2000. Provisional atlas of British hoverflies. Centre for Ecology and Hydrology: Abbotts Ripton. 167 pp.

Doczkal, D. and U. Schmid. 1994. Drei neue arten der Gattung Epistrophe (Diptera: Syrphidae), mit einem Bestimmungsschlüssel für die deutschen Arten. Stuttgarter Beiträge zur Naturkunde Serie A (Biologie) 507: 1-32.

Dusek, J. and P. Laska. 1985. A review of the genus Scaeva Fabricius (Diptera, Syrphidae) with the description of a new species from Chile. Acta Entomologica Bohemoslovaca 82: 206-228.

Falk, S.J. 1991. A Review of the Scarce and Threatened Flies of Great Britain. Peterborough: Nature Conservancy Council. $194 \mathrm{pp}$.

Fluke, C.L. 1950. The male genitalia of Syrphus, Epistrophe and related genera (Diptera, Syrphidae). Transactions of the Wisconsin Academy of Sciences, Arts and Letters 40: 115-148. 
Gilasian, E. 2007. Review of tribe Syrphini (Dip.: Syrphidae) in Iran. Journal of Entomological Society of Iran 27(1): 85-112.

Goeldlin de Tiefenau, P. 1974. Contribution à l'étude systématique et écologique de Syrphidae (Dipt.) de la Suisse occidentale. Mitteilungen der Schweizerischen Entomologischen Gesellschaft 47(1): 151-252.

Khiaban, N.G., R. Hayat, M. Safaralizadeh and M. Parchami. 1998. A faunistic survey of Syrphidae in Uromieh region. Proceeding of the 13th Iranian Plant Protection Congress 1: 231.

Kowalesky, S. 1885. Zusätze und Bemerkungen zu Laplace's Untersuchung über die Gestalt der Saturnsringe. Astronomische Nachrichten 111: $37-48$

Ku, K. 1968. Insects of Mt. Myung-ji (cont'd). Korean Journal of Zoology 11(2): 69-71. (in Korean).

Láska, P. and P. Stary. 1980. Prey records of aphidophagous syrphid flies from Czechoslovakia (Diptera, Syrphidae). Acta Entomologica Bohemoslovaca 77(2): 228-235.

Lutovinovas E. 2003. 14 nauju Lietuvos faunos žiedmusių (Diptera: Syrphidae) rūšių iš Molètų rajono. New and Rare for Lithuania Insect Species, Records and Descriptions 15(1): 28-31.

Mazánek, L., P. Láska, V. Bičík and R .Novotný. 2001. Descriptions with key to the third larval stage and puparia of the genus Epistrophe s.str. (Diptera: Syrphidae). Acta Universitatis Carolinae- Biologica 45(2): 115-128.

Mengual, X., G. Stahls, A. Vujic and M.A. Marcos-Garcia. 2006. Integrative taxonomy of Iberian Merodon species (Diptera, Syrphidae). Zootaxa 1377: $1-26$.

Peck, L.V. 1988. Family Syrphidae; pp. 11-230, in: A. Soos and J. Papp (ed.). Catalogue of Palearctic Diptera. Syrphidae - Conopidae. Volume VIII. Amsterdam: Elsevier.

Reemer, M. 1999. Een derde vindplaats van Scaeva dignota: een soort om op te letten. Zweefvliegennieuwsbrief 4 (2): 16-17.

Rotheray, G.E. 1986. The larva and puparium of Epistrophe grossulariae (Meigen) (Dip., Syrphidae) with a note on overwintering behaviour. Entomologist's Monthly Magazine 122(2): 215-218.

Rotheray, G.E. and F. Gilbert. 1989. The phylogeny and systematics of European predacious Syrphidae (Diptera) based on larval and puparial stages. Zoological Journal of the Linnean Society 95(1): 2970

Rotheray, G.E. 1993. Color guide to hoverfly larvae in Britain and Europe. Dipterist Digest 9(2): 1-156.

Rotheray, G.E. and F. Gilbert. 1999. Phylogeny of Palaearctic Syrphidae (Diptera): evidence from larval stages. Zoological Journal of the Linnean Society 127: 1-112.
Schneider, F. 1948. Beitrag zur Kenntnis der Generationsverhaltnisse und Diapause rauberischer Schwebfliegen (Syrphidae, Diptera). Mitteilungen der Schweizerischen Entomologischen Gesellschaft 21(2): 249-285.

Schneider, F. 1969. Bionomics and physiology of aphidophagous Syrphidae. Annual Review of Entomology 14(3): 103-124.

Speight, M.C.D. 2007. Epistrophe olgae Mutin 1999 (Diptera: Syrphidae) une nouvelle espèce pour la Suisse et la France. Bull.Romand d'Entomologie, 24(3): 41-42.

Speight, M.C.D. 2011. Species accounts of European Syrphidae (Diptera); pp. 74-80, in: M.C.D. Speight, E. Castella, J.P. Sarthou and C. Momteil (ed.): Syrph the Net, the database of European Syrphidae. Volume 65. Dublin: Syrph the Net publications.

Stubbs, A.E. and S.J. Falk. 1983. British Hoverflies, an Illustrated Identification Guide. London: British Entomological and Natural History Society. $253 \mathrm{pp}$.

Thompson, F.C. and G.E, Rotheray. 1998. Family Syrphidae; pp. 81-139, in: Papp, L., Darvas, B. (ed.), Manual of Palaearctic Diptera. Volume III. Budapest: Science Herald.

Thompson, F.C. 2012. Biosystematic Database of World Diptera. Version 7.5. Accessible at http://www.diptera.org/biosys.htm. Captured on 10 August 2012.

Van Veen, M.P. 2004. Hover flies of Northwest Europe: identification keys to the Syrphidae. Utrecht: KNNV Publishing. 254 pp.

Vockeroth, J.R. 1969. A revision of the genera of the Syrphini (Diptera, Syrphidae). Memoirs of the Entomological Society of Canada 62(2): $1-176$.

Vockeroth, J. R. 1992. The flower flies of the subfamily Syrphinae of Canada, Alaska and Greenland. Ottawa: Canada Communications Group. 456 pp.

Vujic A. and S. Glumac. 1994. Fauna osolikih muva (Diptera: Syrphidae) Fruške gore. Monographs of Fruška gora. Novi Sad, Matica srpska, 83 pp.

Wirth, W.W. Y.S. Sedman and H.V. Weems. 1965. Family Syrphidae; pp. 557-627, in: Stone, A., Sabrosky, C.W., Wirth, W.W., Foote and R.H., Coulson, J.R. (ed.). A Catalog of the Diptera of America North of Mexico. Volume 3. Washington, DC: Agricultural Research Service, United States Department of Agriculture.

RECEIVED: May 2012

ACCEPTED: December 2013

PUBLISHED ONLINE: February 2014

EDITORIAL RESPONSIBILITY: Marcelo Ribeiro Pereira 